\title{
Potensi Sekam Padi Sebagai Bahan Bakar Alternatif PLTBm di Sumatra Barat
}

\author{
Tjatur Udjianto $^{1}$, Teguh Sasono ${ }^{2}$, Bambang Puguh Manunggal $^{3}$ \\ Jurusan Teknik Konversi Energi, Politeknik Negeri Bandung \\ email: ${ }^{1}$ tjatur.udjianto@polban.ac.id, ${ }^{2}$ teguhssn@gmail.com, ${ }^{3}$ bambang_energi@ hotmail.com
}

\begin{abstract}
Abstrak
Sekam padi merupakan biomassa yang melimpah di Indonesia, salah satunya di Provinsi Sumatera Barat. Provinsi ini merupakan salah satu Provinsi penghasil beras terbesar di luar Pulau Jawa. Pada tahun 2019 Provinsi Sumatera Barat menghasilkan padi sebesar 1.482 .996 ton-GKG. Sekam padi merupakan hasil sampingan dari penggilingan padi menjadi beras. Produksi sekam padi pada tahun 2019 di provinsi Sumatera Barat adalah sebesar 370.749 ton, sekitar 25\%-nya dari produksi padi. Potensi energi sekam padi di Provinsi Sumatra Barat pada tahun 2019 dengan nilai kalor 13,44 MJ/kg adalah sebesar 4.982.866.594 MJ. Sekam padi sebagai bahan bakar PLTBm mempunyai manfaat mengurangi ketergantungan terhadap sumber energi fosil dan memanfaatkan limbah proses penggilingan padi. Teknologi PLTBm dengan menggunakan alat konversi energi biomassa secara thermal dapat berupa Gasifikasi, pembakaran dan pirolisis. Perhitungan kapasitas terpasang PLTBm diasumsikan menggunakan gasifikasi dengan teknologi pembangkit mesin diesel. Berdasarkan hasil perhitungan kapasitas terpasang PLTBm Provinsi Sumatra Barat adalah sebesar 58,7 MW. Energi listrik gross yang diproduksi PLTBm Provinsi Sumatra Barat adalah sebesar $465.068 \mathrm{MWh}$. Setelah dikurangi Auxiliary power/house load PLTBm, produksi energi listrik net yang dijual atau dimanfaatkan adalah sebesar 444.140 MWh. Dengan dipasangnya PLTBm maka akan menghasilkan penurunan emisi gas rumah kaca dalam satu tahun sekitar 479.902 ton- $\mathrm{CO}_{2}$ ekivalen.
\end{abstract}

Kata Kunci: PLTBm, gasifikasi, sekam padi, gas rumah kaca.

\section{Pendahuluan}

Saat ini energi telah menjadi kebutuhan mendasar dan konsumsi energi semakin meningkat setiap tahunnya. Kebutuhan energi sebagian besar masih dipasok oleh bahan bakar fosil seperti minyak bumi, batubara termasuk gas alam. Seiring dengan semakin menipisnya bahan bakar fosil dan terkait dengan kesadaran akan lingkungan serta komitmen Indonesia untuk menurunkan emisi rumah kaca sebesar $29 \%$ dengan upaya sendiri tanpa bantuan luar negeri pada tahun 2030, maka pengembangan energi baru terbarukan terus didorong dan dimajukan salah satunya adalah biomasa sebagai sumber energi terbarukan.

Sekam padi merupakan biomasa yang melimpah di Indonesia, salah satunya di Provinsi Sumatera Barat. Provinsi ini merupakan salah satu provinsi penghasil beras terbesar di luar Pulau Jawa. Pada tahun 2019 Provinsi Sumatera Barat menghasilkan padi sebesar 1.482.996 ton-GKG. Sekam padi merupakan hasil sampingan dari penggilingan padi menjadi beras. Produksi sekam padi pada tahun 2019 di provinsi Sumatera Barat adalah sebesar 370.749 ton, sekitar 25\%-nya dari produksi padi. Nilai energi yang terkandung dalam sekam padi dengan nilai kalori 13,44 $\mathrm{MJ} / \mathrm{kg}$ adalah sekitar 4.982.866.594 MJ. Sekam padi sebagai bahan bakar PLTBm mempunyai manfaat mengurangi ketergantungan terhadap sumber energi fosil dan memanfaatkan limbah proses penggilingan padi.

Pusat listrik Tenaga Biomasa (PLTBm) adalah merupakan pembangkit yang memanfaatkan sumber energi biomasa. Bahan bakar yang digunakan untuk PLTBm adalah dapat berupa sekam padi, kayu, jerami dan lain sebagainya tergantung dari teknologi dan daerah penghasil biomasa. Teknologi PLTBm dengan menggunakan alat konversi energi biomasa secara thermal dapat berupa gasifikasi, pembakaran dan pirolisis.

Penelitian ini ditujukan khusus untuk menganalisis potensi sekam padi sebagai bahan bakar PLTBm, Teknologi konversi biomasa dan estimasi listrik yang dapat dihasilkan PLTBm. Rencana tempat penelitian sekam padi adalah di Provinsi Sumatra Barat.

\section{Tujuan dan ManfaAt Penelitian}

Tujuan dari penelitian ini adalah melakukan kajian potensi sekam padi sebagai bahan bakar PLTBm di Provinsi Sumatera Barat. Selain itu juga dilakukan kajian teknologi konversi energi sekam padi. Dengan pemanfaatan sekam padi ini dapat dihitung dan dianalisis potensi keuntungan serta penurunan terkait emisi gas rumah kaca. Manfaat yang didapatkan dari hasil penelitian ini adalah diharapkan dapat 
memberikan pengetahuan dan referensi dalam upaya pemanfaatan biomasa khususnya sekam padi serta salah satu upaya dalam penurunan efek gas rumah kaca.

\section{Tinjauan Pustaka}

\subsection{Pendahuluan}

Padi merupakan tanaman utama yang tumbuh di hampir seluruh wilayah Indonesia. Padi menghasilkan beras yang merupakan makan pokok sebagian besar masyarakat Indonesia. Pengolahan padi menjadi beras melalui beberapa tahapan setelah panen yang setiap tahapannya menyisakan limbah yang cukup banyak berupa jerami dan sekam padi. Kedua Jenis limbah olahan padi tersebut memiliki kandungan energi yang dapat dimanfaatkan lebih lanjut.

Sekam padi merupakan lapisan keras yang meliputi kariopsis yang terdiri dari dua belahan yang disebut lemma dan palea yang saling bertautan. Pada proses penggilingan beras sekam akan terpisah dari butir beras dan menjadi bahan sisa atau limbah penggilingan. Sekam dikategorikan sebagai biomasa yang dapat digunakan untuk berbagai kebutuhan seperti bahan baku industri, pakan ternak dan energi atau bahan bakar. Dari proses penggilingan padi biasanya diperoleh sekam sekitar 20-30\% dari bobot gabah [5].

Jerami adalah adalah hasil samping usaha pertanian berupa tangkai dan batang tanaman serealia yang telah kering, setelah biji-bijiannya dipisahkan.

Jerami dan sekam padi merupakan biomass yang dapat dimanfaatkan untuk menghasilkan energi listrik. Biomasa merupakan material yang dapat dimanfaatkan untuk menghasilkan listrik, panas, bahan bakar bio dan produk lainnya. Dianggap sebagai pembawa netral karbon ketika diproduksi dan digunakan secara berkelanjutan, biomasa dapat berkontribusi besar untuk mengurangi emisi gas rumah kaca (GRK).

Biomasa merupakan sebuah istilah untuk semua bahan organik yang berasal dari tumbuh-tumbuhan, termasuk limbah tanaman budidaya, alga dan juga sampah organik. Biomasa dapat dibedakan dalam tiga kelompok besar, yaitu biomasa kayu, biomasa bukan kayu, dan biomasa sekunder. Energy Europe Insitute membagi biomasa kedalam empat kategori yaitu: (i) limbah pertanian, (ii) limbah kehutanan, (iii) tanaman kebun energi, dan (iv) limbah organik [6].

\subsection{Pustaka}

Saat ini banyak publikasi ilmiah yang membahas mengenai pemanfaatan sekam padi sebagai bahan bakar untuk menghasilkan listrik beserta dengan teknologi konversi biomasa seperti gasifikasi, pirolisis maupun pembakaran langsung.serta energi yang dihasilkan.

Beberapa hasil penelitian terkait dengan pemanfaatan sekam padi sebagai energi terbarukan, teknologi konversi biomasa serta potensi energi yang dapat dihasilkan dijadikan referensi oleh peneliti.

Menurut [4] berdasarkan jenis biomasa, sekam padi mempunyai potensi energi $30 \%$ dari total biomasa di Indonesia di bawah palm oil sebesar 39\% serta memberikan penjelasan potensi energi yang dapat dihasilkan dari biomasa di seluruh provinsi di Indonesia. Selain itu juga menjelaskan pengembangan biomasa di Indonesia tahun 2011-2019.

Menurut [1] Indonesia memiliki potensi sumber energi biomasa terbarukan yang sangat besar berupa sekam padi. Potensi sekam padi di Indonesia meluas ke setiap provinsi tetapi belum dimanfaatkan secara optimal untuk menghasilkan energi listrik. dibuang begitu saja sebagai limbah yang mencemari lingkungan. Penelitian yang dilakukan menghasilkan gambaran tentang potensi energi listrik sekam padi tersedia di Indonesia sebagai bahan bakar untuk pembangkit listrik dengan menggunakan angka nilai kalor $13,44 \mathrm{MJ} / \mathrm{kg}$. Dari beberapa penelitian kisaran nilai kalor adalah antara 12,34-14,00 MJ/kg. Sedangkan menurut [2], nilai kalor sekam padi berdasarkan contoh percobaannya adalah sebesar 2938,86 kcal/kg (12,30 MJ/kg).

Penelitian ini akan menyajikan perhitungan potensi energi listrik yang dapat dihasilkan dari sekam padi di provinsi Sumatra Barat. Selain itu juga akan dilakukan estimasi kapasitas daya terpasang berdasarkan skema pembangkit yang ditentukan. Terkait dengan gas rumah kaca akan dihitung potensi penghematannya dibandingkan dengan pembangkit konvensional seperti pembangkit berbahan bakar batubara.

\subsection{Produksi Padi di Sumatra Barat}

Produksi padi Sumatera Barat pada tahun 2019 adalah sebesar 1.482 .996 ton-GKG yang disumbang dari berbagai Kabupaten/Kota yang terdapat di Provinsi Sumatra Barat. Produksi padi tiap Kabupaten/Kota di Provinsi Sumatra Barat tahun 2019 dan perkiraan sementara tahun 2020 dapat dilihat pada gambar di bawah ini.

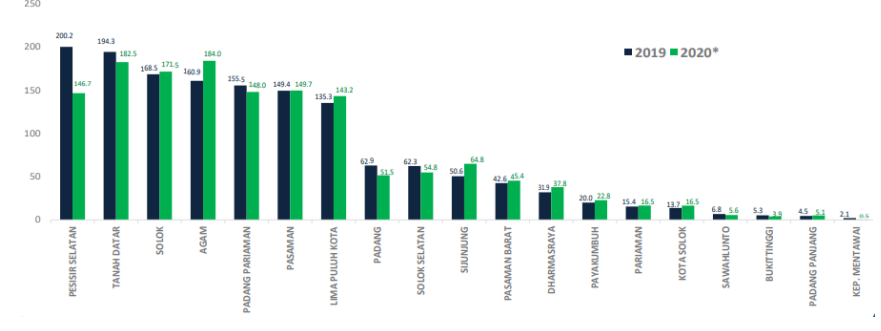

Gambar 1 Produksi Padi di Sumatera Barat per Kabupaten/Kota Tahun 2019 (BRS, 2020)

Berdasarkan gambar tersebut di atas, pada tahun 2019 terdapat tujuh Kabupaten sebagai penghasil padi tertinggi yaitu Kabupaten Agam, Tanah Datar, Solok, Pasaman, Padang Pariaman dan Pesisir Selatan dan Lima Puluh Kota yang menyumbang sekitar $76 \%$ dari 
total produksi padi Sumatera Barat. Sebaran kabupaten penghasil padi tertinggi di Sumatera Barat dapat dilihat pada gambar di bawah ini.

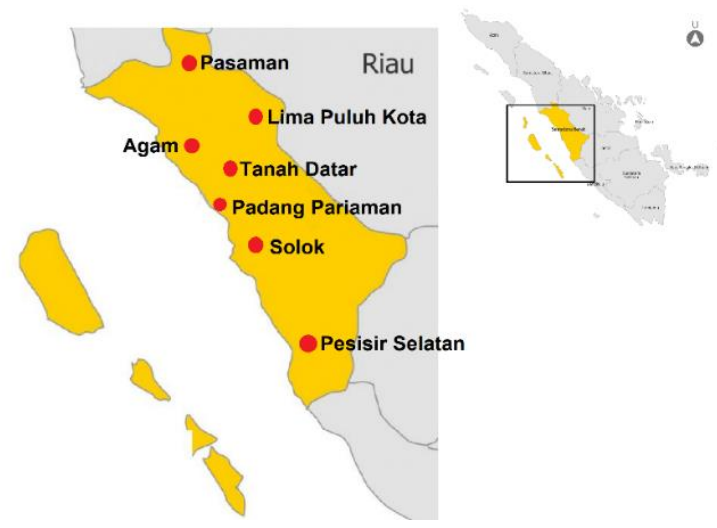

Gambar 2 Peta Sebaran Produksi Padi 2019 di Sumatera Barat

Potensi Sekam padi yang dapat dihasilkan dari 7 Kabupaten penghasil padi tertinggi tersebut adalah sekitar 281.400 ton. Dengan posisi wilayah yang tersebar tersebut dapat menjadi kriteria pertimbangan dalam penentuan kapasitas PLTBm yang akan ditentukan. Selain itu keamanan pasokan sekam padi tentunya menjadi kriteria sebagai pertimbangan dalam penentuan kapasitas. Besar kecilnya produksi sekam padi akan tergantung dari produksi padi serta konsumsi sekam padi untuk kebutuhan lain.

\subsection{Pemanfaatan Sekam Padi}

Sekam padi merupakan salah satu sumber energi terbarukan yang dapat digunakan untuk menghasilkan energi listrik serta dapat mengurangi emisi gas rumah kaca (GRK). Saat ini pemanfaatan sekam padi masih terbatas pada pemanfaatan secara tradisional seperti dibuat arang sekam, pupuk organik dan beberapa manfaat lainnya. Dengan produksi sekam padi yang berlimpah, Konversi sekam padi menjadi energi listrik atau bahan bakar lainnya akan sangat menguntungkan. Penggunaan sekam padi untuk sektor energi khususnya dalam menghasilkan energi listrik akan dapat mengurangi masalah lingkungan seperti menumpuknya sekam padi, pembuangan sekam padi bahkan pembakaran sekam padi serta pengurangan emisi gas rumah kaca.

\subsection{Teknologi Konversi Energi Sekam Padi}

Biomasa dapat dikonversi menjadi energi melalui tiga alur proses yaitu termokimia, biokimia dan ekstraksi biji yang mengandung minyak. Untuk menghasilkan energi listrik, konversi biomasa biasanya menggunakan konversi thermal atau termokimia seperti pembakaran, pirolisis dan gasifikasi [5]. Alur teknologi konversi energi dapat dilihat pada gambar di bawah ini.

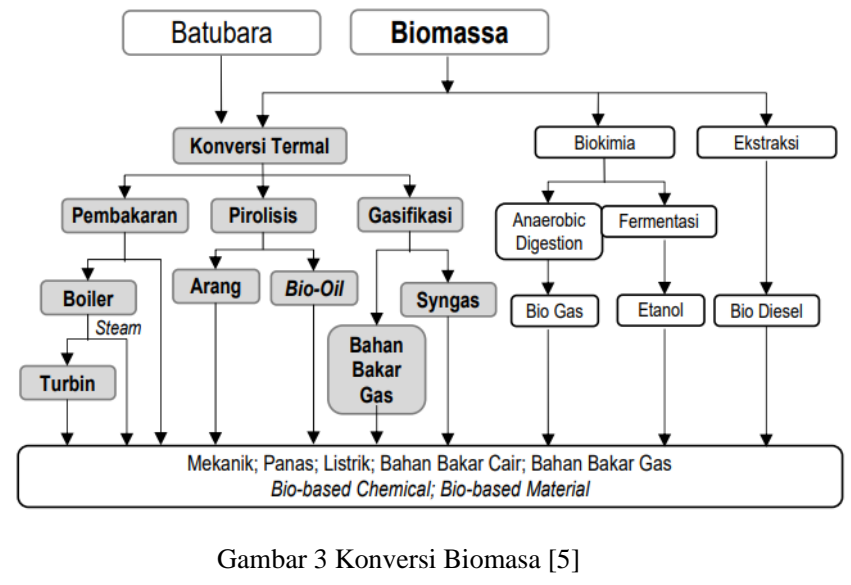

Pembakaran adalah merubah energi yang terkandung dalam bahan bakar menjadi energi panas. Selain menghasilkan energi panas, pembakaran juga menghasilkan karbon dioksida $\mathrm{CO}_{2}$ dan uap air $\mathrm{H}_{2} \mathrm{O}$. Energi panas hasil pembakaran salah satunya dapat dimanfaatkan untuk memanaskan air dan menghasilkan uap di dalam boiler dan memutarkan turbin. Saat ini, khususnya di Indonesia Sebagian besar PLTBm menggunakan sistem pembakaran langsung yang membakar biomasa secara langsung untuk menghasilkan uap.

Proses gasifikasi adalah proses untuk mengubah biomasa menjadi gas sintesis, campuran antara hidrogen dan karbon monoksida. Gas sintesis, atau biasa disebut juga syngas, kemudian dapat diubah secara kimia menjadi bahan bakar atau produk lainnya seperti dibakar dalam boiler, atau bahan bakar untuk mesin gas.

Proses pirolisis ditujukan semula untuk mendapatkan bahan bakar padat, arang dengan kualitas lebih tinggi dari biomasa asalnya. Hasil degradasi biomasa dalam proses pirolisis juga berupa cairan senyawa organik (tar, hidrokarbon berat dan asam-asam organik), dan gas-gas seperti $\mathrm{CO}, \mathrm{CO}_{2}, \mathrm{C}_{2} \mathrm{H}_{2}, \mathrm{C}_{2} \mathrm{H}_{4}, \mathrm{C}_{2} \mathrm{H}_{6}$ [5].

\subsection{Kapasitas Pembangkit PLTBm}

Ukuran atau kapasitas pembangkit PLTBm dibatasi oleh pasokan sekam padi dari penggilingan padi. Ketersediaan sekam padi sebagai sumber bahan bakar dan pembangkit listrik yang dihasilkan dihitung dengan rumus [1].

$R H=R P \times H_{G R} \times C_{E}$

Dengan:

RH : Potensi Sekam Padi (ton)

RP : Produksi Gabah (ton-GKG)

$\mathrm{C}_{\mathrm{E}} \quad$ : Efisiensi Pengumpulan Gabah (\%)

Potensi energi yang dapat dihasilkan dari sekam padi dapat dilihat pada persamaan di bawah ini. 


$$
E P_{R H}=R H \times C V
$$

\section{Dengan:}

$\mathrm{EP}_{\mathrm{RH}}$ : Potensi energi Sekam Padi (MJ)

$\mathrm{CV}$ : Nilai kalor sekam padi (MJ/kg)

Sehingga untuk menghitung kapasitas daya terpasang PLTBm dapat menggunakan persamaan sebagai berikut.

$$
P P_{R H}=\frac{\left(E P_{R H} / C_{f}\right) \times P_{\text {eff }}}{\text { Jam operasi }}
$$

\author{
Dengan: \\ $\mathrm{PP}_{\mathrm{RH}}$ : kapasitas $(\mathrm{kW})$ \\ $\mathrm{P}_{\text {eff }} \quad$ : Efisiensi total PLTBm (\%) \\ $\mathrm{C}_{\mathrm{f}}$ : Faktor konversi (1kWh sama dengan 3,6MJ)
}

\subsection{Teknologi Pembangkit Listrik}

Faktor-faktor yang mempengaruhi penggunaan teknologi yang sesuai adalah ketersediaan sekam padi, rasio heat to power yang dibutuhkan, dan karakteristik bahan bakar. Karakteristik sekam padi merupakan salah satu faktor yang sangat penting dan menentukan teknologi yang akan digunakan, hal ini terkait dengan kandungan abu, kadar air, nilai kalor dan homogenitas yang terkandung dalam sekam padi. Berbagai jenis teknologi yang dapat digunakan untuk konversi energi sekam padi seperti jenis gasifikasi yang terdiri dari fixed bed dan fluidized bed. Fixed bed terdiri dari updraft dan downdraft. Sedangkan fluidized bed terdiri dari bubling fluidized bed dan circulating fluidized bed. Untuk teknologi pembangkit listrik dapat berupa Pembangkit listrik tenaga uap, mesin gas maupun turbin gas.

\section{Hasil dan Pembahasan}

\subsection{Data Produksi Padi}

Data sekunder didapatkan dari Balai Pusat Statistik (BPS) Provinsi Sumatra Barat. Data sekunder yang didapatkan adalah berupa data produksi padi per Kabupaten di Sumatra Barat dalam kurun waktu 20112019. Data sekunder produksi padi dalam kurun waktu 9 tahun terakhir dapat dilihat pada tabel di bawah ini.

Tabel 1 Produksi Padi Provinsi Sumatera Barat Tahun 2011-2019

\begin{tabular}{|c|c|c|c|c|c|c|c|c|c|}
\hline \multirow{2}{*}{$\begin{array}{c}\text { Kabupaten/ } \\
\text { Kota }\end{array}$} & \multicolumn{9}{|c|}{ Produksi Padi (ton-GKG) } \\
\hline & 2011 & 2012 & 2013 & 2014 & 2015 & 2016 & 2017 & 2018 & 2019 \\
\hline Kab.Sijunjung & 75.07 & 70.11 & $\begin{array}{r}80.22 \\
9\end{array}$ & 83.35 & 88.33 & 90.20 & 72.58 & 61.58 & 50.55 \\
\hline Kab.T & $|237.1|$ & 249.7 & 251.3 & 237.6 & 245.1 & 235.6 & 298.9 & 183.1 & 194.2 \\
\hline Ea & 78 & 58 & 41 & 10 & 96 & 36 & 59 & 24 & 67 \\
\hline Kat & 251.0 & 251.5 & 264.8 & 268.9 & 278.1 & 287.0 & 321.3 & 148.2 & 155.4 \\
\hline & 38 & 09 & 18 & 80 & 27 & 46 & 76 & 30 & 75 \\
\hline \multirow[b]{2}{*}{ Kab.Agam } & 276.1 & 296.8 & 306.4 & 322.6 & 326.8 & 372.4 & 405.5 & 178.5 & 160.8 \\
\hline & 12 & 83 & 10 & 18 & 91 & 14 & 78 & 57 & 88 \\
\hline Kab.I & 213.6 & 218.0 & 222.4 & 217.3 & 227.1 & 226.1 & 210.4 & 149.4 & 135.3 \\
\hline Pul & 93 & 93 & 63 & 66 & 84 & 70 & 52 & 87 & 15 \\
\hline \multirow{2}{*}{ Pasaman } & 204.5 & 216.3 & 203.5 & 214.7 & 216.7 & \begin{tabular}{|c|}
191.2 \\
\end{tabular} & 232.4 & 137.5 & 149.4 \\
\hline & 18 & 47 & 58 & 84 & 66 & 82 & 71 & 12 & 41 \\
\hline Kab.S & 121.4 & 140.5 & 127.2 & 133.0 & 136.3 & 118.5 & 128.0 & \begin{tabular}{|c|c|}
64.49 \\
\end{tabular} & 62.32 \\
\hline Sela & 08 & 79 & 44 & 97 & 63 & 30 & 13 & 1 & 7 \\
\hline Kab.Dharmas & \begin{tabular}{|c|}
48.22 \\
\end{tabular} & 59.88 & 54.94 & 62.09 & 57.35 & 59.28 & 58.25 & 33.51 & 32.92 \\
\hline rays & & & 0 & & 6 & 2 & 9 & 2 & 7 \\
\hline Kab.Pasaman & 109.4 & 113.0 & 122.1 & 141.8 & 147.5 & 121.2 & 136.3 & 52.17 & 42.54 \\
\hline Bara & 31 & 84 & 28 & 18 & 28 & 17 & 85 & 2 & 6 \\
\hline \multirow[b]{2}{*}{ Kota Padans } & 74.56 & 78.69 & 86.58 & 90.06 & 88.75 & 82.62 & 84.20 & 56.26 & 62.87 \\
\hline & & & 0 & 4 & & 0 & & 7 & \\
\hline \multirow{2}{*}{ Kota Solok } & 13.07 & 12.59 & 11.22 & 12.72 & 11.75 & 13.29 & 14.27 & 12.38 & 13.73 \\
\hline & & & & & & 0 & & 6 & 8 \\
\hline Kot: & \begin{tabular}{|c|}
12.09 \\
\end{tabular} & 16.16 & 17.53 & 15.07 & 16.65 & 15.05 & 13.64 & & 760 \\
\hline Saw & & & 6 & 6 & & 5 & 6 & 0.10 & 169 \\
\hline $\begin{array}{l}\text { Kota Padang } \\
\text { Panjang }\end{array}$ & 8.945 & 9.443 & 8.630 & 8.074 & 9.481 & $\begin{array}{r}10.34 \\
7 \\
\end{array}$ & $\begin{array}{r}11.60 \\
9 \\
\end{array}$ & 3.72 & 4.533 \\
\hline $\begin{array}{l}\text { Kota } \\
\text { Bukittinggi }\end{array}$ & 027 & 5.472 & 4.411 & 5.053 & 5.096 & 5.227 & 5.204 & 5.481 & 5.266 \\
\hline Ko & 38.88 & 35.33 & 33.12 & 33.42 & 34.41 & 37.40 & 41.15 & 21.31 & 19.95 \\
\hline Pay & & 4 & 3 & 7 & 6 & 2 & 0 & 3 & 8 \\
\hline Ko & 22.43 & 24.55 & 29.77 & 31.25 & 32.09 & 31.04 & 41.83 & 15.72 & 15.39 \\
\hline Paria & 4 & & 6 & & & & & & \\
\hline
\end{tabular}

\begin{tabular}{|l|r|r|r|r|r|r|r|r|r|}
\hline \multirow{2}{*}{$\begin{array}{l}\text { Kabupaten/ } \\
\text { Kota }\end{array}$} & \multicolumn{7}{|c|}{ Produksi Padi (ton-GKG) } \\
\cline { 2 - 10 } & $\mathbf{2 0 1 1}$ & $\mathbf{2 0 1 2}$ & $\mathbf{2 0 1 3}$ & $\mathbf{2 0 1 4}$ & $\mathbf{2 0 1 5}$ & $\mathbf{2 0 1 6}$ & $\mathbf{2 0 1 7}$ & $\mathbf{2 0 1 8}$ & $\mathbf{2 0 1 9}$ \\
\hline Sumatera & 2.279 & 2.368 & 2.430 & 2.519 & 2.550 & 2.503 & 2.824 & 1.483 & 1.482. \\
Barat & 602 & 390 & 384 & 020 & 609 & 452 & 509 & 076 & 996 \\
\hline Kab.Kep.Men & 579,0 & 1.388 & 1.022 & 2.106 & 3.036 & 2.477 & 5.189 & 2.367 & 2.087 \\
tawai & 264.1 & 261.4 & 272.4 & 312.8 & 317.5 & 274.1 & 376.9 & 187.1 & 200.1 \\
\hline Kab.Pesisir & 28 & 68 & 95 & 72 & 73 & 19 & 72 & 25 & 80 \\
Selatan & 304.2 & 307.0 & 332.4 & 326.6 & 307.9 & 330.0 & 366.3 & 163.2 & 168.4 \\
\hline Kab.Solok & 00 & 27 & 55 & 41 & 99 & 82 & 55 & 65 & 52 \\
\hline
\end{tabular}

Berdasarkan tabel tersebut di atas, Data produksi padi pada periode 2011-2019 berfluktuatif dengan tren cenderung turun. Berdasarkan data BPS terakhir produksi padi tahun 2020 menurun lagi dibandingkan dengan tahun 2019 dengan nilai sebesar 1.387.269 tonGKG. Data ini perlu dilihat lebih jelas lagi dengan periode antara tahun 2011-2017 dan 2018-2019 serta tahun terakhir 2020. Pada periode tahun 2011-2017 produksi padi di Provinsi Sumatra Barat cenderung naik terus dan periode tahun 2018-2020 cenderung turun. Kecenderungan turunnya produksi disebabkan salah satunya oleh luas panen padi yang menurun.

Akan tetapi pada periode tahun 2011-2017 dan 20182020 terjadi perbedaan data produksi padi yang sangat jauh untuk tiap tahunnya. Sebagai contoh pada tahun 2017 dan 2018 perbedaan data produksi padi adalah sekitar $47 \%$ dan hal tersebut tidak mungkin disebabkan hanya karena faktor luas panen padi yang menurun. Salah satu kemungkinan yang dapat terjadi dapat disebabkan karena perbedaan data. Hal ini dkuatkan dengan siaran berita yang menyatakan bahwa beberapa tahun terakhir ini target produksi padi di Sumbar diklaim sebesar 3 juta ton. Namun untuk tahun 2021 ini Dinas Tanaman Pangan Hortikultura dan Perkebunan Sumbar menyatakan target produksi padi hanya sebesar 1,5 juta ton. Alasan diturunkannya target produksi padi 
itu, karena ada perbedaan hitungan dasar antara Dinas Tanaman Pangan Hortikultura dan Perkebunan Sumbar dengan Badan Pusat Statistik (BPS) soal produksi padi.

\subsection{Potensi Produksi Sekam Padi}

Produksi sekam padi akan tergantung dari produksi padi yang dihasilkan termasuk di Provinsi Sumatra Barat. Potensi sekam padi yang dihasilkan dari gabah (GKG) adalah antara 20-30\%. Dalam perhitungan potensi sekam padi pada penelitian ini digunakan angka moderat sebesar 25\%. Hasil produksi sekam padi dari gabah (GKG) dapat dilihat pada tabel di bawah ini.

Tabel 2 Potensi Sekam Padi Provinsi Sumatera Barat Tahun 2011-2019

\begin{tabular}{|c|c|c|c|c|c|c|c|c|c|}
\hline \multirow{2}{*}{$\begin{array}{l}\text { Kabupaten/ } \\
\text { Kota }\end{array}$} & \multicolumn{9}{|c|}{ Potensi Sekam Padi (Ton) } \\
\hline & 2011 & 2012 & 2013 & 2014 & 2015 & 2016 & 2017 & 2018 & 2019 \\
\hline & 9.9 & 592.0 & 607.5 & 629.7 & 637.6 & 625.8 & 706.1 & 370.7 & 370.7 \\
\hline are & 01 & & & $5=$ & & ${ }^{\prime}$ & 0 & 69 & 40 \\
\hline ab. & 145 & 347 & 256 & 527 & 759 & 619 & 1.297 & 592 & 522 \\
\hline ab. & 6.0 & 36 & 2 & 8.21 & 7 & 8.53 & 4.24 & 6.78 & 50.04 \\
\hline ela & 2 & 7 & & 0 & 3 & 0 & 3 & 1 & 5 \\
\hline & 76.05 & 76.75 & 83.11 & 81.66 & 77.00 & 82.52 & 91.58 & 40.81 & 42.11 \\
\hline $\mathrm{du}$. & 0 & 7 & 4 & 0 & 0 & 1 & 9 & 6 & 3 \\
\hline & 18.76 & 17.52 & 20.05 & 20.83 & 22.08 & 22.55 & 18.14 & 15.39 & 12.64 \\
\hline$a b$. & 9 & 8 & 7 & 9 & 5 & 2 & 6 & 6 & 0 \\
\hline $\mathrm{ab}$ & 59.29 & 62.43 & 62.83 & 59.40 & 61.29 & 58.90 & 74.74 & 45.78 & 48.5 \\
\hline ata & 5 & 9 & 5 & 3 & 9 & 9 & 0 & 1 & 7 \\
\hline$a b$ & 62.76 & 62.87 & 66.20 & 67.24 & 69.53 & 71.76 & 80.34 & 37.05 & 38.8 \\
\hline & 0 & 7 & 5 & 5 & 2 & 2 & 4 & 8 & 9 \\
\hline & 69.02 & 74.22 & 76.60 & 80.65 & 81.72 & 93.10 & 101.3 & 44.63 & 40.22 \\
\hline & 8 & 1 & 3 & 5 & 3 & 4 & 95 & 9 & 2 \\
\hline$a b$. & 53.42 & 54.52 & 55.61 & 54.34 & 56.79 & 56.54 & 52.61 & 37.37 & 33.82 \\
\hline Ko & 3 & 3 & 6 & 2 & 6 & 3 & 3 & 2 & 9 \\
\hline & 51.13 & 54.08 & 50.89 & 53.69 & 54.19 & 47.82 & 58.11 & 34.37 & 37.36 \\
\hline 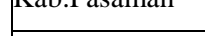 & 0 & 7 & 0 & 6 & 2 & 1 & 8 & 8 & 0 \\
\hline $\mathrm{cab}$ & 30.35 & 35.14 & 31.81 & 33.27 & 34.09 & 29.63 & 32.00 & 16.12 & 15.58 \\
\hline & 2 & 5 & 1 & 4 & 1 & 3 & 3 & 3 & 2 \\
\hline$a b$. & 12.05 & 14.97 & 13.73 & 15.52 & 14.33 & 14.82 & 14.56 & & \\
\hline & 5 & 1 & 5 & 3 & 9 & 1 & 5 & & \\
\hline & 27.35 & 28.27 & 30.53 & 35.45 & 36.88 & 30.30 & 34.09 & 13.04 & 10.63 \\
\hline $3 a 1$ & 8 & 1 & 2 & 5 & 2 & 4 & 6 & 3 & 7 \\
\hline & 18.64 & 19.67 & 21.64 & 22.51 & 22.18 & 20.65 & 21.05 & 14.06 & 15.71 \\
\hline & 2 & 5 & 3 & 6 & 8 & 5 & 0 & 7 & 9 \\
\hline cota & .269 & 3.148 & 2.806 & 3.181 & 2.939 & 3.323 & 3.568 & 3.096 & 3.434 \\
\hline & 023 & 4.041 & 4.384 & 769 & 4.164 & 3.764 & 3.412 & 1.691 & 1.692 \\
\hline & 236 & 2.361 & 2.158 & 01 & 370 & $2.58^{\prime}$ & 2.902 & 930 & 1.133 \\
\hline & .007. & 1.368 & 1.10 & 1.263 & 1.27 & 1.307 & $\mid 1.301$ & 1.370 & 1.31 \\
\hline Kota & .720 & 8.834 & 3.2 & 8.35 & 8.60 & 9.351 & $\begin{array}{c}10.28 \\
8 \\
\end{array}$ & 5.32 & 4.9 \\
\hline 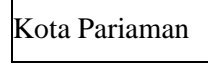 & 5.609 & 6.139 & 7.4 & 7.815 & 8.023 & 7.762 & $\begin{array}{c}10.4 \\
9\end{array}$ & 3.930 & 3.84 \\
\hline
\end{tabular}

Berdasarkan tabel tersebut di atas, potensi sekam padi pada periode 2011-2019 berfluktuatif dan dengan tren cenderung turun. Pada tahun 2020 produksi sekam padi adalah sebesar $346.817,25$ ton. Pada empat tahun terakhir terlihat bahwa potensi sekam padi cenderung turun. Kecenderungan turunnya produksi sekam padi akan menjadi indikasi dan pertimbangan penentuan penentuan skema dan ukuran kapasitas PLTBm terpasang, sehingga pembangkit dapat beroperasi secara berkelanjutan.

\subsection{Potensi Energi Sekam Padi}

Perhitungan potensi energi yang terkandung dalam sekam padi menggunakan data produksi padi pada tahun 2019 di Provinsi Sumatra Barat. Perhitungan Potensi energi yang terkandung dalam sekam padi menggunakan persamaan (1). Asumsi dan parameter yang digunakan dalam perhitungan potensi energi yang terkandung dalam sekam padi adalah nilai kalor sekam padi $13,44 \mathrm{MJ} / \mathrm{kg}$ dan efisiensi pengumpulan $100 \%$ dengan asumsi ideal tidak ada kehilangan, sekam padi dimanfaatkan semua untuk bahan bakar PLTBm. Perhitungan potensi energi yang terkandung dalam sekam padi dilakukan per Kabupaten serta total Provinsi Sumatra Barat. Contoh perhitungan potensi energi yang terkandung dalam sekam padi di Kabupaten Mentawai tahun 2019 dapat dilihat pada persamaan di bawah ini.

\section{$R H=522 \times 13,44 \times 100 \%=7013126$ MJ $/$ Tahun}

Hasil perhitungan untuk masing-masing Kabupaten di Provinsi Sumatra Barat dapat dilihat pada tabel di bawah ini.

Tabel 3 Energi Potensial Sekam Padi Provinsi Sumatra Barat Tahun 2019

\begin{tabular}{|l|r|r|r|}
\hline \multicolumn{1}{|c|}{$\begin{array}{c}\text { Kabupaten/ } \\
\text { Kota }\end{array}$} & $\begin{array}{c}\text { Produksi Padi } \\
\text { (ton-GKG) }\end{array}$ & $\begin{array}{c}\text { Sekam Padi } \\
\text { (ton) }\end{array}$ & \multicolumn{1}{c|}{$\begin{array}{c}\text { Potensi Energi } \\
\text { (MJ/Tahun) }\end{array}$} \\
\hline Sumatera Barat & 1.482 .996 & 370.749 & 4.982 .866 .594 \\
\hline Kab.Kep.Mentawai & 2.087 & 522 & 7.013 .126 \\
\hline Kab.Pesisir Selatan & 200.180 & 50.045 & 672.604 .262 \\
\hline Kab.Solok & 168.452 & 42.113 & 565.998 .754 \\
\hline Kab.Sijunjung & 50.559 & 12.640 & 169.879 .080 \\
\hline Kab.Tanah Datar & 194.267 & 48.567 & 652.735 .474 \\
\hline $\begin{array}{l}\text { Kab.Padang } \\
\text { Pariaman }\end{array}$ & 155.475 & 38.869 & 522.396 .437 \\
\hline Kab.Agam & 160.888 & 40.222 & 540.584 .554 \\
\hline $\begin{array}{l}\text { Kab.Lima Puluh } \\
\text { Kota }\end{array}$ & 135.315 & 33.829 & 454.658 .198 \\
\hline Kab.Pasaman & 149.441 & 37.360 & 502.120 .618 \\
\hline Kab.Solok Selatan & 62.327 & 15.582 & 209.418 .048 \\
\hline Kab.Dharmasraya & 32.927 & 8.232 & 110.635 .123 \\
\hline Kab.Pasaman Barat & 42.546 & 10.637 & 142.955 .333 \\
\hline Kota Padang & 62.877 & 15.719 & 211.267 .526 \\
\hline Kota Solok & 13.738 & 3.434 & 46.159 .176 \\
\hline Kota Sawahlunto & 6.769 & 1.692 & 22.744 .109 \\
\hline $\begin{array}{l}\text { Kota Padang } \\
\text { Panjang }\end{array}$ & 4.533 & 1.133 & 15.230 .746 \\
\hline
\end{tabular}




\begin{tabular}{|l|r|r|r|}
\hline $\begin{array}{c}\text { Kabupaten/ } \\
\text { Kota }\end{array}$ & $\begin{array}{c}\text { Produksi Padi } \\
\text { (ton-GKG) }\end{array}$ & $\begin{array}{c}\text { Sekam Padi } \\
\text { (ton) }\end{array}$ & $\begin{array}{c}\text { Potensi Energi } \\
\text { (MJ/Tahun) }\end{array}$ \\
\hline Kota Bukittinggi & 5.266 & 1.317 & 17.694 .802 \\
\hline Kota Payakumbuh & 19.958 & 4.989 & 67.057 .973 \\
\hline Kota Pariaman & 15.391 & 3.848 & 51.713 .256 \\
\hline
\end{tabular}

Berdasarkan tabel tersebut di atas, energi potensial sekam padi terbesar adalah di Kabupaten Pesisir Selatan, Kabupaten Tanah Datar dan Kabupaten Solok. Jumlah Total energi potensial Sekam padi untuk Provinsi Sumatra Barat adalah sebesar 4.982.867.594 MJ/tahun.

\subsection{Skema PLTBm}

Maksud skema PLTBm dalam penelitian ini adalah jenis teknologi, kapasitas serta instalasi PLTBm yang cocok untuk diaplikasikan berdasarkan pada beberapa variabel utama seperti kuantitas dan kualitas sumber biomasa, tingkat pembelian listrik lokal, dan pertimbangan geografis.

Pertimbangan kuantitas adalah terkait dengan ketersediaan biomasa dalam hal ini sekam padi yang akan digunakan sebagai bahan bakar PLTBm. Kuantitas sekam padi ini juga harus dipertimbangkan dengan penggunaan lainnya di wilayah ini seperti untuk pupuk dan lain sebagainya. Kualitas dan kuantitas sekam padi akan menentukan besar kecilnya kapasitas dan teknologi PLTBm yang akan digunakan.

Tingkat pembelian listrik lokal terkait dengan kemampuan PLTBm untuk memasok listrik ke lingkungan sekitar, kebutuhan listrik pabrik penggilingan padi maupun disalurkan ke grid PLN. Pilihan sistem sebagian besar tergantung pada ekonomi. Biaya bahan bakar, tingkat daya yang dapat dijual, serta berbagai faktor ekonomi.

Pertimbangan geografis terkait dengan lokasi dipasangnya PLTBm, salah satunya diusahakan mendekati sumber air baku seperti sungai. Selain itu Lokasi PLTBm diusahakan mendekati sumber bahan bakar biomasa dan beban yang akan dipasok atau apabila akan dijual ke grid PLN, mendekati titik sambung milik PLN.

Proses konversi biomasa yang biasanya digunakan untuk PLTBm adalah konversi thermal atau termokimia seperti pembakaran langsung, gasifikasi dan pirolysis. Pembakaran langsung dengan mengumpankan sekam padi kedalam boiler, memanaskan air, menghasilkan uap untuk memutarkan turbin dan menghasilkan listrik. Selain itu juga biomasa dapat dijadikan bahan bakar untuk co-firing dengan batubara untuk boiler konvensional. Gasifikasi adalah proses untuk menghasilkan syngas yang selanjutnya dapat diumpankan kedalam mesin gas, boiler dan gas turbin sebagai pengganti bahan bakar gas alam.

\subsection{Kapasitas PLTBm}

Dalam menentukan kapasitas PLTBm yang terpasang, skema PLTBm yang digunakan adalah gasifikasi dengan menggunakan mesin gas atau diesel dual fuel. Lokasi pembangkit dekat dengan sumber bahan bakat dan juga sumber air.

Selanjutnya dilakukan perhitungan potensi kapasitas PLTBm yang dapat dipasang untuk merubah energi yang terkandung dalam sekam padi menjadi energi listrik. Berikut ini beberapa asumsi dan parameter yang digunakan untuk perhitungan kapasitas PLTBm yang dipasang. Sebagai berikut:

\begin{tabular}{ll} 
Efisiensi thermal gasifikasi & $: 80 \%$ \\
Efisiensi total mesin gas & $: 42 \%$ \\
Efisiensi total PLTBm & \multicolumn{1}{c}{$: 34 \%$} \\
Jam operasi per hari & $: 24$ jam \\
Hari operasi/tahun & $: 330$ hari \\
jam operasi/tahun & $: 7920$ jam
\end{tabular}

Hasil perhitungan untuk masing-masing Kabupaten di Provinsi Sumatra Barat berdasarkan potensi energi yang terkandung dalam sekam padi dan asumsi yang ditentukan di atas, dapat dilihat pada tabel di bawah ini.

Tabel 4 Kapasitas Terpasang PLTBm Provinsi Sumatra Barat

\begin{tabular}{|c|c|c|c|}
\hline Kabupaten/Kota & \begin{tabular}{|c|}
$\begin{array}{c}\text { Produksi Padi } \\
\text { (ton-GKG) }\end{array}$ \\
\end{tabular} & $\begin{array}{c}\text { Sekam Padi } \\
\text { (ton) }\end{array}$ & $\begin{array}{c}\text { Potensi Daya } \\
\text { Terpasang }(\mathbf{k W}) \\
\end{array}$ \\
\hline Sumatera Barat & 1.482 .996 & 370.749 & 58.721 \\
\hline Kab.Kep.Mentawai & 2.087 & 522 & 82,65 \\
\hline Kab.Pesisir Selatan & 200.180 & 50.045 & $7.926,31$ \\
\hline Kab.Solok & 168.452 & 42.113 & $6.670,02$ \\
\hline Kab.Sijunjung & 50.559 & 12.640 & $2.001,94$ \\
\hline Kab.Tanah Datar & 194.267 & 48.567 & $7.692,17$ \\
\hline $\begin{array}{l}\text { Kab.Padang } \\
\text { Pariaman }\end{array}$ & 155.475 & 38.869 & $6.156,19$ \\
\hline Kab.Agam & 160.888 & 40.222 & $6.370,53$ \\
\hline $\begin{array}{ll}\text { Kab.Lima } & \text { Puluh } \\
\text { Kota } & \\
\end{array}$ & 135.315 & 33.829 & $5.357,92$ \\
\hline Kab.Pasaman & 149.441 & 37.360 & $5.917,25$ \\
\hline Kab.Solok Selatan & 62.327 & 15.582 & $2.467,89$ \\
\hline Kab.Dharmasraya & 32.927 & 8.232 & $1.303,78$ \\
\hline Kab.Pasaman Barat & 42.546 & 10.637 & $1.684,66$ \\
\hline Kota Padang & 62.877 & 15.719 & $2.489,68$ \\
\hline Kota Solok & 13.738 & 3.434 & 543,96 \\
\hline Kota Sawahlunto & 6.769 & 1.692 & 268,03 \\
\hline $\begin{array}{ll}\text { Kota } & \text { Padang } \\
\text { Panjang } & \\
\end{array}$ & 4.533 & 1.133 & 179,49 \\
\hline Kota Bukittinggi & 5.266 & 1.317 & 208,52 \\
\hline Kota Payakumbuh & 19.958 & 4.989 & 790,25 \\
\hline Kota Pariaman & 15.391 & 3.848 & 609,42 \\
\hline
\end{tabular}

Total potensi kapasitas terpasang PLTBm untuk wilayah Provinsi Sumatra Barat adalah sebesar 58.721 kW yang tersebar di $19 \mathrm{Kota} /$ Kabupaten. Kapasitas 
terpasang PLTBm yang paling besar adalah di Kabupaten Pesisir Selatan dan yang terendah adalah di Kabupaten Kepulauan Mentawai.

Apabila skema satu pembangkit PLTBm untuk Provinsi Sumatra Barat maka kapasitas terpasang adalah sekitar 58,7 MW. Dengan jumlah sebesar itu maka PLTBm dapat koneksi ke jaringan atau grid PLN.

Akan tetapi hal ini tidak mungkin secara ekonomis karena wilayah yang tersebar sangat luas, terkendala dengan transportasi sekam padi. Skema yang Lebih memungkinkan adalah tiap kabupaten atau tiap wilayah tertentu berdasarkan radius lokasi sumber bahan bakar sekam padi, sehingga dalam Provinsi Sumatra Barat akan terdapat beberapa unit PLTBm. Tidak menutup kemungkinan sumber bahan bakar akan terjadi lintas Kabupaten, seperti Kabupaten dan kota Solok, Sawahlunto, Pasaman, Payakumbuh dapat terdiri dari satu unit PLTBm, sehingga kapasitasnya dapat mencapai sekitar 8MW. Kapasitas sebesar ini dapat digunakan untuk memasok listrik ke penduduk sekitar, penggunaan penggilingan beras atau masuk ke jaringan/grid PLN.

Untuk kapasitas kecil seperti dibawah $500 \mathrm{~kW}$ dapat digunakan untuk memasok listrik ke penggilingan beras dan menggantikan listrik PLN atau diesel. Penentuan skema PLTBm tersebut tentunya membutuhkan pertimbangan-pertimbangan teknis dan ekonomis serta geografis terkait dengan letak sumber bahan bakar, sumber air dan juga sumber beban serta rencana titik sambung ke jaringan/grid PLN.

\subsection{Perhitungan Produksi Energi}

Perhitungan produksi energi tahunan didapatkan dari jumlah daya listrik terpasang dikalikan dengan jumlah jam operasi. Asumsi yang digunakan adalah dalam satu tahun PLTBm beroperasi selama 7920 jam/tahun. Produksi energi tahunan tiap kabupaten di Provinsi Sumatra Barat dapat dilihat pada tabel di bawah ini.

Tabel 5 Produksi Energi Listrik (gross) PLTBm Provinsi Sumatra Barat

\begin{tabular}{|l|r|r|r|r|}
\hline \multicolumn{1}{|c|}{$\begin{array}{c}\text { Kabupaten } \\
\text { /Kota }\end{array}$} & $\begin{array}{c}\text { Sekam } \\
\text { Padi } \\
\text { (ton) }\end{array}$ & \multicolumn{1}{|c|}{$\begin{array}{c}\text { Potensi } \\
\text { Energi } \\
\text { (MJ/Tahun) }\end{array}$} & $\begin{array}{c}\text { Potensi Daya } \\
\text { Terpasang } \\
\text { (kW) }\end{array}$ & $\begin{array}{c}\text { Produksi Energi } \\
\text { Tahunan Gross } \\
\text { (MWH) }\end{array}$ \\
\hline Sumatera Barat & 370.749 & 4.982 .866 .594 & 58.721 & 465.068 \\
\hline $\begin{array}{l}\text { Kab.Kep.Menta } \\
\text { wai }\end{array}$ & 522 & 7.013 .126 & 82,65 & 654,56 \\
\hline $\begin{array}{l}\text { Kab.Pesisir } \\
\text { Selatan }\end{array}$ & 50.045 & 672.604 .262 & $7.926,31$ & $62.776,40$ \\
\hline Kab.Solok & 42.113 & 565.998 .754 & $6.670,02$ & $52.826,55$ \\
\hline Kab.Sijunjung & 12.640 & 169.879 .080 & $2.001,94$ & $15.855,38$ \\
\hline Kab.Tanah Datar & 48.567 & 652.735 .474 & $7.692,17$ & $60.921,98$ \\
\hline $\begin{array}{l}\text { Kab.Padang } \\
\text { Pariaman }\end{array}$ & 38.869 & 522.396 .437 & $6.156,19$ & $48.757,00$ \\
\hline Kab.Agam & 40.222 & 540.584 .554 & $6.370,53$ & $50.454,56$ \\
\hline $\begin{array}{l}\text { Kab.Lima Puluh } \\
\text { Kota }\end{array}$ & 33.829 & 454.658 .198 & $5.357,92$ & $42.434,77$ \\
\hline
\end{tabular}

\begin{tabular}{|l|r|r|r|r|}
\hline \multicolumn{1}{|c|}{$\begin{array}{c}\text { Kabupaten } \\
\text { /Kota }\end{array}$} & $\begin{array}{c}\text { Sekam } \\
\text { Padi } \\
\text { (ton) }\end{array}$ & \multicolumn{1}{c|}{$\begin{array}{c}\text { Potensi } \\
\text { Energi } \\
\text { (MJ/Tahun) }\end{array}$} & \multicolumn{1}{c|}{$\begin{array}{c}\text { Potensi Daya } \\
\text { Terpasang } \\
\text { (kW) }\end{array}$} & $\begin{array}{c}\text { Produksi Energi } \\
\text { Tahunan Gross } \\
\text { (MWH) }\end{array}$ \\
\hline Kab.Pasaman & 37.360 & 502.120 .618 & $5.917,25$ & $46.864,59$ \\
\hline $\begin{array}{l}\text { Kab.Solok } \\
\text { Selatan }\end{array}$ & 15.582 & 209.418 .048 & $2.467,89$ & $19.545,68$ \\
\hline $\begin{array}{l}\text { Kab.Dharmasray } \\
\text { a }\end{array}$ & 8.232 & 110.635 .123 & $1.303,78$ & $10.325,94$ \\
\hline $\begin{array}{l}\text { Kab.Pasaman } \\
\text { Barat }\end{array}$ & 10.637 & 142.955 .333 & $1.684,66$ & $13.342,50$ \\
\hline Kota Padang & 15.719 & 211.267 .526 & $2.489,68$ & $19.718,30$ \\
\hline Kota Solok & 3.434 & 46.159 .176 & 543,96 & $4.308,19$ \\
\hline $\begin{array}{l}\text { Kota } \\
\text { Sawahlunto }\end{array}$ & 1.692 & 22.744 .109 & 268,03 & $2.122,78$ \\
\hline $\begin{array}{l}\text { Kota Padang } \\
\text { Panjang }\end{array}$ & 1.133 & 15.230 .746 & 179,49 & $1.421,54$ \\
\hline Kota Bukittinggi & 1.317 & 17.694 .802 & 208,52 & $1.651,51$ \\
\hline $\begin{array}{l}\text { Kota } \\
\text { Payakumbuh }\end{array}$ & 4.989 & 67.057 .973 & 790,25 & $6.258,74$ \\
\hline Kota Pariaman & 3.848 & 51.713 .256 & 609,42 & $4.826,57$ \\
\hline
\end{tabular}

Perhitungan produksi energi dalam satu tahun dengan asumsi dan parameter tersebut di atas didapatkan bahwa produksi energi listrik dalam satu tahun untuk Provinsi Sumatra Barat adalah sebesar 465.068 MWh. Nilai produksi energi listrik ini masih gross atau output generator, belum dikurangi kebutuhan sendiri (auxiliary power atau house load). seperti pendinginan, pompa dan lain sebagainya dengan perkiraan sekitar 4,5\% dari produksi energi gross, Konsumsi energi untuk auxiliary power/house load dan produksi listrik nett tiap Kabupaten di Provinsi Sumatra Barat dapat dilihat pada tabel di bawah ini.

Tabel 6 Produksi Energi Listrik (nett) PLTBm Provinsi Sumatra Barat

\begin{tabular}{|c|c|c|c|c|}
\hline Kabupaten/Kota & \begin{tabular}{c|} 
Potensi \\
Daya \\
Terpasang \\
$(\mathbf{k W})$ \\
\end{tabular} & \begin{tabular}{|c|} 
Produksi \\
Energi \\
Tahunan Gross \\
(MWH) \\
\end{tabular} & \begin{tabular}{|c|} 
Auxiliary \\
Power/House \\
Load \\
(MWH) \\
\end{tabular} & $\begin{array}{l}\text { Produksi } \\
\text { Energi } \\
\text { Nett } \\
\text { (MWH) } \\
\end{array}$ \\
\hline Sumatera Barat & 58.721 & 465.068 & 20.928 & 444.140 \\
\hline Kab.Kep.Mentawai & 82,65 & 654,56 & 29,46 & 625,10 \\
\hline Kab.Pesisir Selatan & $7.926,31$ & $62.776,40$ & $2.824,94$ & $59.951,46$ \\
\hline Kab.Solok & $6.670,02$ & $52.826,55$ & $2.377,19$ & $50.449,36$ \\
\hline Kab.Sijunjung & $2.001,94$ & $15.855,38$ & 713,49 & $15.141,89$ \\
\hline Kab.Tanah Datar & $7.692,17$ & $60.921,98$ & $2.741,49$ & $58.180,49$ \\
\hline $\begin{array}{l}\text { Kab.Padang } \\
\text { Pariaman }\end{array}$ & $6.156,19$ & $48.757,00$ & $2.194,07$ & $46.562,94$ \\
\hline Kab.Agam & $6.370,53$ & $50.454,56$ & $2.270,46$ & $48.184,10$ \\
\hline $\begin{array}{l}\text { Kab.Lima Puluh } \\
\text { Kota }\end{array}$ & $5.357,92$ & $42.434,77$ & $1.909,56$ & $40.525,20$ \\
\hline Kab.Pasaman & $5.917,25$ & $46.864,59$ & $2.108,91$ & $44.755,68$ \\
\hline Kab.Solok Selatan & $2.467,89$ & $19.545,68$ & 879,56 & $18.666,13$ \\
\hline Kab.Dharmasraya & $1.303,78$ & $10.325,94$ & 464,67 & $9.861,28$ \\
\hline Kab.Pasaman Barat & $1.684,66$ & $13.342,50$ & 600,41 & $12.742,09$ \\
\hline Kota Padang & $2.489,68$ & $19.718,30$ & 887,32 & $18.830,98$ \\
\hline Kota Solok & 543,96 & $4.308,19$ & 193,87 & $4.114,32$ \\
\hline
\end{tabular}




\begin{tabular}{l}
\hline \multicolumn{4}{|c|}{ Jurnal Energi } & \multicolumn{3}{c|}{ Volume 11 Nomor 1 } \\
\begin{tabular}{|l|c|c|r|c|}
\hline Kabupaten/Kota & $\begin{array}{c}\text { Potensi } \\
\text { Daya } \\
\text { Terpasang } \\
(\mathbf{k W})\end{array}$ & $\begin{array}{c}\text { Produksi } \\
\text { Energi } \\
\text { Tahunan Gross } \\
\text { (MWH) }\end{array}$ & $\begin{array}{c}\text { Auxiliary } \\
\text { Power/House } \\
\text { Load } \\
\text { (MWH) }\end{array}$ & $\begin{array}{c}\text { Produksi } \\
\text { Energi } \\
\text { Nett } \\
\text { (MWH) }\end{array}$ \\
\hline Kota Sawahlunto & 268,03 & $2.122,78$ & 95,53 & $2.027,26$ \\
\hline $\begin{array}{l}\text { Kota Padang } \\
\text { Panjang }\end{array}$ & 179,49 & $1.421,54$ & 63,97 & $1.357,57$ \\
\hline Kota Bukittinggi & 208,52 & $1.651,51$ & 74,32 & $1.577,20$ \\
\hline Kota Payakumbuh & 790,25 & $6.258,74$ & 281,64 & $5.977,10$ \\
\hline Kota Pariaman & 609,42 & $4.826,57$ & 217,20 & $4.609,37$ \\
\hline
\end{tabular}
\end{tabular}

Total potensi produksi energi listrik PLTBm Provinsi Sumatra Barat adalah 440.140 MWh per tahun dengan kebutuhan Auxiliary power/house load sekitar 20.928 MWh.

\subsection{Perhitungan Emisi Gas Rumah Kaca}

Salah satu keuntungan dalam penggunaan biomasa sebagai sumber energi listrik adalah sebagai pengganti bahan bakar fosil yang dapat mengurangi emisi gas rumah kaca. Pada PLTBm yang memanfaatkan biomasa seperti sekam padi dianggap mempunyai sifat karbon netral, yaitu karbon yang dilepaskan ke atmosfir merupakan hasil fotosintesis dan digunakan kembali untuk menumbuhkan kembali tanaman/pohon atau padi. Akan tetapi perlu dipertimbangkan emisi yang dapat ditimbulkan dari proses pengolahan lahan misalnya menggunakan traktor dan proses pasca panen seperti transportasi menuju penggilingan padi. Emisi gas rumah kaca untuk biomasa tidak termasuk emisi pemanasan global dari perubahan penggunaan lahan adalah sekitar 0,04 dan 0,2 lbs/kWh $\mathrm{CO}_{2}$ ekivalen. Nilai tersebut lebih rendah dibandingkan dengan gas alam yang setara 0,6 dan $2 \mathrm{lbs} / \mathrm{kWh} \mathrm{CO}_{2}$ ekivalen atau dengan batubara antara 1,4 dan 3,6 lbs/kWh $\mathrm{CO}_{2}$ ekivalen [3].

Berdasarkan nilai tersebut di atas, maka estimasi emisi gas rumah kaca dari PLTBm dengan produksi listrik nett 440.140MWh per tahun untuk Provinsi Sumatra Barat dengan mengambil nilai rata-rata tersebut di atas adalah sekitar 24.197 ton $\mathrm{CO}_{2}$ ekivalen. Nilai tersebut lebih rendah dibandingkan dengan gas alam sebesar 262.131 ton/tahun $\mathrm{CO}_{2}$ ekivalen dan bahan bakar batubara sebesar 504.098 ton/tahun $\mathrm{CO}_{2}$ ekivalen. Penurunan emisi gas rumah kaca dengan dibangunnya PLTBm dibandingkan apabila menggunakan pembangkit konvensional dengan bahan bakar batubara adalah sebesar 479.902 ton/tahun $\mathrm{CO}_{2}$ ekivalen.

\section{KESIMPULAN}

Berdasarkan dari hasil perhitungan dan analisis yang telah dilakukan, didapatkan kesimpulan sebagai berikut:

1. Potensi sekam padi yang dihasilkan di Provinsi Sumatra Barat tahun 2019 adalah sebesar 370.749 ton. Energi yang terkandung dalam sekam padi tersebut adalah sekitar 4.982.866.594 MJ.

2. Kapasitas total terpasang PLTBm berbahan bakar sekam padi di Provinsi Sumatra Barat adalah sekitar 58,7 MW.

3. Energi listrik gross yang dihasilkan PLTBm dalam periode satu tahun adalah sebesar 465.068 MWh. Dengan kebutuhan auxiliary power/house load sebesar $20.928 \mathrm{MWh}$ atau 4,5\% dari energi listrik yang dihasilkan, maka produksi energi listrik nett adalah sekitar 444.140 MWh.

4. Estimasi penurunan emisi gas rumah kaca dipasangnya PLTBm dibandingkan dengan pembangkit konvensional berbahan bakar batubara adalah sebesar 479.902 ton/tahun $\mathrm{CO}_{2}$ ekivalen.

\section{SARAN}

Untuk penelitian yang akan datang dapat dilanjutkan dengan penelitian yang lebih dalam potensi PLTBm ini dengan melakukan peramalan produksi padi dalam 10 atau 15 tahun kedepan, metoda penentuan kapasitas terpasang PLTBm dengan mempertimbangkan kemungkinan kecenderungan penurunan produksi padi. Selain itu juga dipetakan lokasi penggilingan padi dan sumber air baku untuk menentukan teknologi dan skema PLTBm yang akan diaplikasikan.

\section{REFERENSI}

[1] Anshar, M., Ani, F. N., \& Kader, A. S. (2016). Electrical Energy Potential of Rice Husk As Fuel For Power Generation In Indonesia. ARPN Journal of Engineering and Applied Sciences, 3616-3624.

[2] Awulu, J., Omale, P., \& Ameh, J. (2018). Comparative Analysis of Calorific Values of Selected Agricultural Waste. NIJOTECH, Vol.37 No.4.

[3] Martínez, J. F., Gómez, L. M., Guzmán, M. F., Vanegas, N. C., \& Ruíz, y. D. (2020). Energy from Biomass: Alternative for the Reduction of Atmospheric Emissions. Lampaskos, 70-78.

[4] Primadita, D., Kumara, I., \& Ariastina, W. (2020). A Review on Biomass For Electricity. Journal of Electrical, Electronics and Informatics, Vol 4 no.1.

[5] Pujotomo, I. (2017). Potensi Pemanfaatan Biomassa Sekam Padi Untuk Pembangkit Listrik Melalui Teknologi Gasifikasi. Jurnal Energi dan Kelistrikan, 126-135.

[6] Susanto, H. (2018). Pengembangan Teknologi Gasifikasi untuk Mendukung Kemandirian Energi dan Industri Kimia. Bandung: Institut Teknologi Bandung. 